\title{
BILATERAL PALLIDOTOMY FOR GENERALIZED DYSTONIA
}

\author{
Hélio A. G. Teive1, Daniel Simões de Sá', César Vinícius Grande², \\ Affonso Antoniuk², Lineu Cesar Werneck ${ }^{1}$
}

\begin{abstract}
Objective: To evaluate the efficacy and safety of bilateral pallidotomies in five patients with generalized dystonia. Background: Generalized dystonias are frequently a therapeutic challenge, with poor responses to pharmacological treatment. GPi (globus pallidus internus) pallidotomies for Parkinson's disease ameliorate all kinds of dyskinesias/dystonia, and recent studies reported a marked improvement of refractory dystonias with this procedure. Methods: Five patients with generalized dystonias refractory to medical treatment were selected; one posttraumatic and four idiopathic. The decision to perform bilateral procedures was based on the predominant axial involvement in these patients. Dystonia severity was assessed with the Burke-FahnMarsden Dystonia Scale (BFM). Simultaneous procedures were performed in all but one patient, who had a staged procedure. They were reevaluated with the same scale (BFM) by an unblinded rater at 1, 2, 3, 30, 60, 90, 120 and 180 days post-operatively. Results: The four patients with idiopathic dystonia showed a progressive improvement up to three months; the patient with posttraumatic dystonia relapsed at three months. One patient had a marked improvement, being able to discontinue all the medications. A mean decrease in the BFM scores of $52,58 \%$ was noted. One patient had a trans-operative motor seizure followed by a transient hemiparesis secondary to rack hemorrhage; other was lethargic up to three days after the procedure. Conclusions: Our results show that bilateral GPi pallidotomies may be a safe and effective approach to medically refractory generalized dystonias; it can also be speculated that the posttraumatic subgroup may not benefit with this procedure.
\end{abstract}

KEY WORDS: dystonia, pallidotomy, stereotactic surgery.

\begin{abstract}
Palidotomia bilateral para distonias generalizadas
RESUMO - As distonias generalizadas são freqüentemente um desafio terapêutico, com pobres respostas aos tratamentos farmacológicos. As cirurgias estereotáxicas, como a palidotomia, têm sido utilizadas com êxito no tratamento da doença de Parkinson e estudos recentes relatam importante melhora das distonias generalizadas, refratárias ao tratamento farmacológico, com a palidotomia bilateral. 0 objetivo dos autores foi avaliar a eficácia e segurança da palidotomia bilateral em cinco pacientes com distonia generalizada. Foram selecionados cinco pacientes com distonia generalizada, predominante axial, refratários ao tratamento farmacológico (quatro idiopáticas e uma pós-traumática). A severidade da distonia foi avaliada através da escala de Burke-Fahn-Marsden (BFM), no $1^{\circ}, 2^{\circ}$, e $3^{\circ}$ dia após a cirurgia e nos dias 30, 60, 90, 120 e 180 do pós-operatório. Quatro pacientes com distonia idiopática tiveram uma progressiva melhora dentro de 3 meses após a cirurgia e o paciente com distonia pós-traumática teve uma piora da distonia após 3 meses da cirurgia. Um dos pacientes teve uma melhora acentuada do quadro de distonia, ficando livre das medicações. Em média ocorreu redução de $52,58 \%$ dos escores da escala de BFM. Um dos pacientes teve crise convulsiva no trans-operatório, seguida por hemiparesia transitória secundária a hemorragia cerebral e um outro paciente ficou letárgico nos três dias após o procedimento cirúrgico, com melhora posterior do nível de consciência . Os nossos resultados mostraram que a palidotomia bilateral pode ser uma abordagem segura e efetiva para o tratamento das distonias generalizadas refratárias ao tratamento clínico. Pode-se especular que o subgrupo de distonias generalizadas pós-traumáticas podem não se beneficiar da palidotomia bilateral.
\end{abstract}

PALAVRAS-CHAVE: distonia, palidotomia, cirurgia estereotáxica.

Generalized dystonias are frequently a therapeutic challenge, with a significant group of patients not benefiting from medical therapies, not being able to titrate the doses to an effective level or losing effect on the following months ${ }^{1,2}$. The growing experience with pallidal lesions for Parkinson's disease shows frequent improvement of all kind of dyskinesias/dystonias, including the ones not related to

\footnotetext{
${ }^{1}$ Division of Neurology, Department of Internal Medicine, Hospital de Clínicas, Federal University of Paraná PR, Brazil; ${ }^{2}$ Division of Neurosurgery, Department of Surgery, Hospital de Clínicas, Federal University of Paraná PR, Brazil.
}

Received 14 August 2000, received in final form 26 December 2000. Accepted 29 December 2000.

Dr. Helio A G Teive - Avenida Batel 1230 / 108 - 80420-090 Curitiba PR - Brasil. Fax 41244 5060. E-mail: hagteive@mps.com.br 
L-Dopa therapy ${ }^{3-11}$. These findings, along with some recent reports of marked improvement in medically refractory dystonias prompted us to evaluate the effectiveness of this procedure in a group of selected patients $^{12-16}$.

\section{METHOD}

Patients with medically refractory generalized dystonias were selected from the Movement Disorders Clinic of the Universidade Federal do Paraná. Dystonia severity was assessed pre-operatively and at 1, 2, 3, 30, 60, 90, 120 and 180 days post-operatively by an unblinded rater, using the Burke-Fahn-Marsden Dystonia Scale (BFM) ${ }^{17}$. Informed consent was obtained from all patients before the procedure.

The decision to perform bilateral procedures was based on the predominant axial involvement of the five patients ${ }^{13}$. General anesthesia was obtained with propofol (Just for use of the frame and Stereotomography). Localization of the GPi (globos pallidus internus) was obtained with a head frame (Micromar TM- 03B) and $2 \mathrm{~mm}$ CT (Computed tomography) axial slices (tickness), with gap slices each 2 $\mathrm{mm}$. Leksell's target as modified by Laitinen was used: 2$3 \mathrm{~mm}$ anterior to the midcomissural point, $5 \mathrm{~mm}$ inferior to the AC-PC line and $18-22 \mathrm{~mm}$ lateral to midline. A thermistor electrode (with $1,2 \mathrm{~mm}$ in diameter and $3 \mathrm{~mm}$ of exposed tip electrode- Micromar) connected with a radiofrequency generator (GRF - Micromar) was used to map the internal capsule and the optic tract. The estimulations parameters, performed with the patient awake, were capsular and visual answers (frequency in Hertz $X$ Volts). Three lesions were performed then $2 \mathrm{~mm}$ apart from each other, in the same route. Lesions Parameters were : $1 @$ lesion (test) $=50^{\circ}$ Celsius and 30 seconds, Definitive lesions $=$

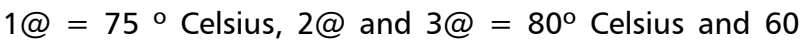
seconds (three lesions in the same route, each $2 \mathrm{~mm}$ ). CTs were used to post-operative lesion evaluation; in all patients lesion placement seemed to be adequate; MRIs (Magnetic Ressonance Images) were not available to confirm this CT impression.

Five patients were selected for the procedure, all of them with predominantly axial involvement. One patient (Case 1) had a posttraumatic dystonia, and the other four, idiopathic forms. Only one was tested for DYT1 (genetic locus for generalized dystonia tipo I), which was negative (Case 4). None had family history of dystonia. The previous mean follow-up of this patients was 2.5 years, and all of them showed poor responses to a variety of combination regimens, including L-dopa, baclofen, trihexyphenidil, tetrabenazine, benzodiazepines and EMG-guided botulinum toxin (BTX). They underwent bilateral simultaneous procedures with the exception of Case 2, which had a staged procedure, after 3 months.

\section{RESULTS}

Only one was tested for DYT1, which was negative (Case 4).
The answers of electrical estimulation, during the surgery, were : capsulars answers $=5 \mathrm{hz}$ (frequency) and 4-6 Volts; visual answers $=75 \mathrm{~Hz}$ and 2-3 Volts. In just one patient a visual response was obtained.

A discrepancy between the tomography target and final target were observed in two patients (Case 2 and 5).

Overall there was a moderate to marked improvement; this was evident not only as the subjective improvement reported by the patients but also as noted on the BFM scales, that showed a mean decrease of $52,58 \%$. The improvement was typically progressive up to three months. One patient was able to discontinue all the medications.

Case 1 (posttraumatic dystonia) showed marked improvement in the immediate post-operative period, but relapsed three months later. The only significant side effects noted were the motor seizure/ transient hemiparesis associated with track hemorrhage of case 2 and a transient lethargy in case 4. Two patients spontaneously reported weight gain.

Tables 1 and 2 depict the clinical characteristics of the patients and BFM values pre and post-operatively.

Table 1. Patient characteristics.

\begin{tabular}{ccccc}
\hline Case & $\begin{array}{c}\text { Age at } \\
\text { onset (year) }\end{array}$ & $\begin{array}{c}\text { Initial site } \\
\text { of dystonia }\end{array}$ & Etiology & DYT1 \\
\hline 1 & 37 & Neck & Posttraumatic & Not tested \\
2 & 16 & Neck & Idiopathic & Not tested \\
3 & 5 & Left leg & Idiopathic & Not tested \\
4 & 23 & Neck & Idiopathic & Negative \\
5 & 21 & Neck & Idiopathic & Not tested \\
\hline
\end{tabular}

Table 2. Surgical outcomes.

\begin{tabular}{cccccc}
\hline $\begin{array}{c}\text { Case } \\
\text { tive BFM }\end{array}$ & $\begin{array}{c}\text { BFM at } \\
\text { 3 days }\end{array}$ & $\begin{array}{c}\text { BFM at } \\
3 \text { months }\end{array}$ & $\begin{array}{c}\text { BFM at } \\
6 \text { months }\end{array}$ & Complications \\
\hline 1 & 51 & 15 & 51 & 51 & None \\
$2 *$ & 60 & $52 / 46$ & 18 & 18 & $\begin{array}{c}\text { Motor } \\
\text { seizure } \\
\text { hemiparesis }\end{array}$ \\
3 & 50 & 50 & 28 & 28 & None \\
4 & 48 & 40 & 6 & 4 & Lethargy \\
5 & 28 & 24 & 12 & 12 & None \\
\hline
\end{tabular}

BFM, Burke-Fahn-Marsden Dystonia Scale; *after stage 1 and 2, respectively. 


\section{Case Report}

Case 1 . This 40 years old male, without family history of any kind of movement disorders, sustained a severe head injury in a motor vehicle accident. CT scans performed while he was in the intensive care unit (ICU) showed diffuse edema and a hygroma over the convexities, later reabsorbed. Discharged from the ICU on the fourth day, he developed involuntary torsion movements on the tenth day over the cervical region, which rapidly spread downwards, predominantly over the axial musculature. On physical examination, prominent retrocolis and dystonic posturing/movements over the trunk and right arm were visible, persisting on rest, with mild involvement of the other three limbs; a dysarthria rendered his speech very hard to understand. On the three years that followed the accident, he was tried on various combinations of benzodiazepines, anticholinergics, baclofen, and tetrabenazine and EMG-guided BTX with minimal improvement. A bilateral simultaneous GPi pallidotomy was performed, and marked improvement was evident immediately after the procedure. The drug dosage was reduced, but after three months, the patient had a relapse to baseline status.

Case 2. This 35 years old male first noticed cervical dystonic movements at 16 years, with relentlessly progressive spread to cranial muscles, limbs and axial musculature. Multiple combinations of drugs, including botulinum toxin on selected muscles were tried with minimal improvement, and then he was submitted to left pallidotomy. During the surgical procedure, the patient had a motor seizure later proved to be secondary to track hemorrhage; he had modest improvement of the contralateral dystonic symptoms but also a hemiparesis. After the improvement of the hemiparesis, a contralateral pallidotomy was performed (three months later), with progressive improvement of the dystonic symptoms including axial muscles.

Case 4 . This 28 years old male had a history of progressive dystonic movements/postures over the last five years; it began in the cervical region and spread to axial muscles first and then to the four limbs, with little involvement of cranial muscles. Multiple combinations of drugs were ineffective, and a bilateral pallidotomy was performed. After the surgery he developed a marked lethargy that subsided three days later. The dystonic symptoms showed a progressive improvement over the following six months, allowing all the medication to be discontinued. Additional follow-up at eight months showed no relapse.

\section{DISCUSSION}

Our patients showed a progressive improvement up to three months (case 4 up to six months), as reported in other series ${ }^{13-15}$. One remarkable exception was case 1 , who had a marked improvement in the immediate post-operative period and relapsed three months later ${ }^{16}$. This might be due to an imperfect lesion placement, in the same way as reported for Parkinson's disease and its dyskinesias and other dystonic patients ${ }^{14,18-20}$. The lack of microelectrode recording may further compromise a perfect placement of the lesion ${ }^{18-21}$. The reason why it took three months to relapse raises some questions; the posttraumatic group may not be amenable to this procedure; Ondo and colleagues reported a poorer result also in a patient with posttraumatic dystonia, although there was no history of relapse. Lesion placement do not seem to be an issue ${ }^{14}$. The fact behind the immediate improvement in this particular patient also remains to be explained; differences in pathophysiology of diverse subgroups of dystonia may explain the observed differences of benefit/relapse and the different time patterns. Besides that, it seems that all subgroups of dystonias may benefit with pallidotomies, even the paroxistics and that ones related to progressive neurodegenerative disea$\operatorname{ses}^{14,15,21-23}$.

We cannot speculate on differences of response based on genetic testing since our patients were not tested for the DYT1 mutation; in fact, only one case had a clinical history compatible with that mutation $^{24,25}$.

The progressive improvement of the patients in our and others reports is also something to be explained. Some putative mechanisms involve relearning of motor tasks, relief of muscle contractures, plasticity and physiological adaptations to the new firing pattern, 13,14 as is suggested even by the known delay of basal ganglia lesions in provoking dystonia. ${ }^{26,27}$

Conclusions about unilateral or bilateral procedures may not be derived from our study, since we have realized only bilateral procedures, based on the predominant axial involvement of our sample. In the only patient with staged procedure, axial dystonic symptoms relief was evident only after the second stage. In Parkinson's disease, unilateral procedures have been reported to loose effect in axial symptoms over time ${ }^{28}$. A higher frequency of side effects would be expected with bilateral procedures ${ }^{28}$, and one may try to avoid that with contralateral deep brain stimulation (DBS) ${ }^{29}$. 
Side effects were rather mild in our sample, although only the Mini-Mental Status Examination and the confrontation method of testing visual fields were performed to detect the abnormalities reported with pallidotomies ${ }^{4,30-34}$. The only patient with dysarthric speech was already with that deficit before the procedure (Case 2). Two patients reported weight gain, and that may be secondary to a decreased energy need, improved ability to eat or some effect on hypothalamic mediated metabolism ${ }^{14}$. In Parkinson's disease, the weight gain is frequently correlated with improvement in "off" periods ${ }^{34}$.

The pathophysiology of dystonia is not a settled issue, although consistent evidence suggests altered basal ganglia outflow ${ }^{35-38}$. Different reports suggest an increased activity in the direct pathway ${ }^{20,37,39}$. The level of activity in the indirect pathway is more controversial: physiological studies, based on the mean discharge rates suggest an increased activity also on this pathway; studies with dopamine ligand receptors suggest a reduced activity ${ }^{20,39}$. GPi firing rates(as well as GPe) are reduced in dystonic patients as compared to Parkinson's disease patients or parkinsonian primates, but slightly faster than reported in patients with hemiballismus ${ }^{13,20,40,41}$. Pallidal activity also seems to correlate inversely with dystonia severity $^{42}$. No human data on normal firing rates are available for comparison. Based on these reported findings, alternative views of basal ganglia functioning are needed to explain the benefits on dystonia and parkinsonian symptoms with a pallidal lesion. In fact, in the known model of basal ganglia, Parkinson's disease is a hypokinetic disorder and dystonia/hemiballismus are hyperkinetic ones - so they should have opposite responses with the same lesion ${ }^{43}$.

Also noted in physiologic studies of basal ganglia are the widening of receptive fields and irregularly grouped discharges in GPi (compared to the tonic pattern reported in normal primates $)^{20}$. These findings may be more relevant pathophysiologically than the abnormal rate; the therapeutic effect of this procedure on dystonic symptoms, as well as on dyskinesias in Parkinson's disease, might be due to a disruption of this abnormal firing and restoration of the normal spatial-temporal patterning of cortical output $^{20}$. This theory is particularly attractive, because it potentially explains, using the old model of basal ganglia functioning, the therapeutic effects of pallidal as well as thalamic lesions reported for Parkinson's disease, dystonia and hemiballismus ${ }^{41}$. The hypothetical advantage of GPi lesions over the thalamic ones would rely on its upstream location, potentially removing this altered input to brainstem regions ${ }^{20}$.
The side effects with pallidotomy noted in our and other reports seemed to be less prominent than with thalamotomies; the beneficial effect on dystonic symptoms also seem to be a little more pronounced (particularly over axial muscles), although a formal comparison is impossible due to different characteristics of each study 12-15,20,22,23,44-46. In previous reports, thalamotomies appear to benefit most patients with secondary dystonias and appendicular symptoms ${ }^{45,46}$; our and Ondo results are suggestive of less benefit at least in a subgroup of the secondary dystonias: the posttraumatic ${ }^{14,16}$. With bilateral procedures, we have noticed marked improvement of axial symptoms.

To clarify the indications of these two procedures, as well as predict which subgroups of dystonic patients would benefit most, further studies are needed, comparing the two procedures in various subgroups of patients with longer follow-ups. The exact place of DBS, either as a first surgical approach or as a second approach after unilateral pallidotomy, also needs further definition ${ }^{29,47}$. The physiological studies performed along with the surgical procedures may also be able to further define different patterns of functioning in the basal ganglia for various subgroups of dystonia, paving the way to a future complete understanding of dystonia pathophysiology ${ }^{20}$.

\section{REFERENCES}

1. Cardoso F, Jankovic J. Dystonia and dyskinesia. Psychiatr Clin N Am 1997; 20:821-838

2. Brin MF. Treatment of dystonia. In Jankovic J, Tolosa E (eds.) Parkinson's disease and movement disorders. 3Ed. Baltimore: Williams and Wilkins, 1998:553-578.

3. Favre J, Taba Jm, Nguyen TT, et al. Pallidotomy: a survey of current practice in North America. Neurosurgery 1996;39:883-892.

4. Lang AE, Lozano A, Montgomery E, et al. Posteroventral medial pallidotomy in advanced Parkinson's disease. N Engl J Med 1997; 337:1036-1042

5. Baron MS, Vitek JL, Bakay RAE, et al. Treatment of advanced Parkinson's disease by posterior GPi pallidotomy: 1 year results of a pilot study. Ann Neurol 1996;40:355-366.

6. Kishore A, Turnbull IM, Snow BJ, et al. Efficacy, stability and predictors of outcome of pallidotomy for Parkinson's disease: six months follow-up with additional one year observation. Brain 1997;120:729-738.

7. Iacono RP, Shima F, Lonser RR, et al. The results, indications and physiology of posteroventral pallidotomy for patients with Parkinson's disease. Neurosurgery 1995;36:1118-1127.

8. Dogali M, Fazzini E, Kolodny E, et al. Stereotactic ventral pallidotomy for Parkinson's disease. Neurology 1995;5:753-761.

9. Johanson F, Malm J, Nordh E, et al. Usefulness of pallidotomy in advanced Parkinson's disease. J Neurol Neurosurg Psychiatry 1997;62:125132.

10. Fazzini E, Dogali M, Sterio D, et al. Stereotactic pallidotomy for Parkinson's disease: a long-term follow-up of unilateral pallidotomy. Neurology 1997;48:1273-1277.

11. Laitinen LV. Pallidotomy for Parkinson's disease. Neurosurg Clin N Am 1995;6:105-112.

12. Iacono R, Kuniyoshi S, Lonser R, et al. Simultaneous bilateral pallidoansotomy for idiopathic dystonia musculorum deformans. Pediatr Neurol 1996;14:145-148.

13. Lozano AM, Kumar R, Gross RE, et al. Globus pallidus internus pallidotomy for generalized dystonia. Mov Disord 1997;12:865-870. 
14. Ondo WG, Desaloms JM, Jankovic J, et al. Pallidotomy for generalized dystonia. Mov Disord 1998;13:693-698.

15. Iacono RP, Kuniyoshi SM, Schoonenberg T. Experience with stereotactics for dystonia: case examples. In Fahn S, Marsden CD, DeLong MR (eds). Dystonia 3. Philadelphia: Lippincott-Raven, 1998:221-226

16. Teive H, Sá DS, Grande CV, et al. Bilateral simultaneous globus pallidus internus pallidotomy for generalized posttraumatic dystonia (Abstract). Mov Disord 1998; 13(suppl 2):P1.053.

17. Burke RE, Fahn S, Marsden CD, et al. Validity and reliability of a rating scale for the primary torsion dystonias. Neurology 1985;35:73-77.

18. Gross RE, Lombardi WJ, Lang AE, et al. Relationship of lesion location to clinical outcome following microelectrode-guided pallidotomy for Parkinson's disease. Brain, 1999;122:405-416.

19. Lang AE. Surgical treatment of dystonia. In Fahn S, Marsden CD, DeLong MR, (eds). Dystonia 3. Philadelphia: Lippincott-Raven, 1998:185-198.

20. Vitek JL, Zhang J, Evatt M, et al. GPi pallidotomy for dystonia: clinical outcome and neuronal activity. In Fahn S, Marsden CD, DeLong MR, eds. Dystonia 3. Philadelphia: Lippincott-Raven, 1998:211-219.

21. Alterman RL, Sterio D, Beric A, Kelly PJ. Microelectrode recording during posteroventral pallidotomy: impact on target selection and complications. Neurosurgery 1999;44:315-321.

22. Bhatia KP, Marsden CD, Thomas DGT. Posteroventral pallidotomy can ameliorate attacks of paroxysmal dystonia induced by exercise. J Neurol Neurosurg Psychiatry 1998;65:604-605.

23. Justesen CR, Penn RD, Kroin JS, et al. Stereotactic pallidotomy in a child with Hallervorden-Spatz disease. J Neurosurg 1999;90:551-554.

24. Kramer PL, Heiman GA, Bressman SB, et al. The DYT1 gene on 9q34 is responsible for most case of early limb-onset idiopathic torsion dystonia in non-Jews. Ann J Hum Genet 1994;55:468-475.

25. Raymond D, Bressman SB, Sabatti C. The DYT1 phenotype (Abstract). Neurology 1999;52(suppl 2):A116.

26. Elble RJ. Motor control and movement disorders. In Jankovic J, Tolosa E (eds). Parkinson's disease and movement disorders. 3Ed. Baltimore: Williams and Wilkins, 1998:15-45.

27. Pettigrew LC, Jankovic J. Hemidystonia: a report of 22 patients and a review of the literature. J Neurol Neurosurg Psychiatry 1985;48:650-657.

28. Obeso JA, Guridi J, Alvarez L, et al. Ablative surgery for Parkinson's disease. In Jankovic J, Tolosa E (eds). Parkinson's disease and movement disorders. 3Ed. Baltimore: Williams and Wilkins, 1998:1049-1064.

29. Vitek JL, Evatt M, Zhang J, et al. Pallidotomy and deep brain stimulation as a treatment for dystonia (Abstract). Neurology 1999;52(suppl 2): A294.

30. Trepanier LL, Saint-Cyr JA, Lozano AM, et al. Neuropsychological consequences of posteroventral pallidotomy for the treatment of Parkinson's disease. Neurology 1998;51:207-215.
31. Stebbins GT, Gabrieli JDG, Shannon KM, et al. Impaired fronto-striatal cognitive functioning following posteroventral pallidotomy in advanced Parkinson's disease (Abstract). Neurology 1999; 52(suppl 2):A513-514.

32. Scott R, Gregory R, Hines N. Neuropsychological, neurological and functional outcome following pallidotomy for Parkinson's disease: a consecutive series of eight simultaneous bilateral and twelve unilateral procedures. Brain 1998,121:659-675.

33. Biousse V, Newman NJ, Carroll C. Visual fields in patients with posterior Gpi pallidotomy. Neurology 1998;50:258-265.

34. Lang AE, Lozano AM, Tasker RR, et al. Neuropsychologic and behavioral changes and weight gain after medial pallidotomy. Ann Neurol 1997;41:834-835.

35. Karbe H, Holthoff VA, Rudolf J, et al. Positron emission tomography demonstrates frontal cortex and basal ganglia hypometabolism in dystonia. Neurology 1992;42:1540-1544.

36. Bhatia KP, Marsden CD. The behavioural and motor consequences of focal lesions of the basal ganglia in man. Brain 1994;117:859-876.

37. Eidelberg D, Moeller JR, Ishikawa T, et al. The metabolic topography of idiopathic torsion dystonia. Brain 1995;118:1473-1484.

38. Bucher SF, Seelos KC, Dodel RC, et al. Pallidal lesions: structural and functional magnetic resonance imaging. Arch Neurol 1996;53:682-686.

39. Perlmutter JS, Stambuk MK, Markham KT, et al. Decreased $\left[{ }^{18} \mathrm{~F}\right] \mathrm{spi}-$ perone binding in idiopathic focal dystonia. J Neurosci 1997;17:843850

40. Filion M, Tremblay L. Abnormal spontaneous activity of globus pallidus neurons in monkeys with MPTP-induced parkinsonism. Brain Res 1991;547:142-151.

41. Suarez JI. Pallidotomy for hemiballismus: efficacy and characteristics of neuronal activity. Ann Neurol 1997;42:807-811.

42. Lenz FA, Suarez JI, Verhagen Metman L, et al. Pallidal activity during dystonia: somatosensory reorganisation and changes with severity. J Neurol Neurosurg Psychiatry 1998;65:767-770.

43. Penney JB, Young AB. Speculations on the functional anatomy of basal ganglia disorders. Ann Rev Neurosci 1983;6:73-94.

44. Cooper IS. 20-year follow-up study of the neurosurgical treatment of dystonia musculorum deformans. Adv Neurol 1976;14:170-177.

45. Tasker RR, Doorly T, Yamashiro K. Thalamotomy in generalized dystonia. Adv Neurol 1988;50:615-631.

46. Cardoso F, Jankovic J, Grossman RG, et al. Outcome after stereotactic thalamotomy for dystonia and hemiballismus. Neurosurgery 1995;36:501-508

47. Brin MF, Germano I, Danisi FO, et al. Deep brain stimulation (DBS) of pallidum in intractable dystonia (Abstract). Mov Disord 1998; 13 (Suppl 2): P4.236. 